\title{
Zbigniew Tucholski
}

Instytut Historii Nauki im. L. i A. Birkenmajerów PAN

ORCID 0000-0002-4171-4128

\section{Fotografia lotnicza jako źródło historyczne Aerial Photography as a Historical Source}

Aerial photographs are extremely valuable, often underestimated historical sources. Their use gives very positive results pertaining to research in the field of military history. Photographs documenting the events of World War II constitute primary sources of great importance in many areas of historical research in which archival sources have not survived. As documented by case studies, they validate the legitimacy of basing research methodology on photographic documents. Following a short historical outline on the development of aerial photography, the author analyzes some cases related to Warsaw's destruction and reconstruction of its urban layout, as well as the murders committed by the NKVD in Kharkiv and Mednoye.

Keywords: aerial photography, military history, destruction of Warsaw after the Warsaw Uprising, Katyn Massacre, history of the development of the railway network

Słowa kluczowe: fotografia lotnicza, historia wojskowości, zniszczenie Warszawy po Powstaniu Warszawskim, Zbrodnia Katyńska, historia rozwoju sieci kolejowej

\section{Wprowadzenie}

W początkowej części artykułu przedstawiono najważniejsze zagadnienia związane z powstaniem i rozwojem fotografii lotniczej na tle przemian technologicznych i militarnych. Takie ujęcie ma istotne znaczenie dla ukazania znaczenia fotografii lotniczej jako źródła historycznego w zmieniającej się rzeczywistości technologicznej i militarnej XX w. Fotografia lotnicza staje się bowiem w wielu wypadkach unikatowym źródłem historycznym, szczególnie wobec zniszczenia, rozproszenia lub braku dostępu do oryginalnej dokumentacji aktowej lub technicznej. 
Ponieważ w polskiej historiografii istnieje niewiele publikacji dotyczących tej tematyki ${ }^{1}$, w artykule wykorzystano szeroko relacje osób prowadzących od wielu lat prace w zakresie badań archiwalnych zdjęć lotniczych. Duże znaczenie metodologiczne ma praca A. Ciołkosza, J. Miszalskiego i J.R. Olędzkiego Interpretacja zdjęć lotniczych (Warszawa 1978), zawierająca rozdział dotyczący historii powstania i rozwoju fotografii lotniczej. Istotną wartość w zakresie interpretacji zdjęć lotniczych jako źródła historycznego ma również publikacja Z. Jabłońskiego i M. Sinkiewicza Klucz fotointerpretacyjny wybranych elementów środowiska kulturowego środkowej części Polski północnej (Toruń 1993). Zawarto w niej opis techniki interpretacji zdjęć lotniczych wywodzący się z fotogrametrii wojskowej.

Powstanie fotografii lotniczej było przełomem technologicznym umożliwiającym utrwalenie obrazu topograficznego z przestworzy. Zapis taki, oprócz znaczenia militarnego, kartograficznego, geologicznego i gospodarczego, posiada również wartość źródła historycznego.

Pierwsze archeologiczne zastosowanie fotografii lotniczej w Polsce związane było z rozpoznaniem stanowisk i dokumentacją prac wykopaliskowych. W 1928 r. z inicjatywy archeologa Konrada Jażdżewskiego wykonano z wojskowego hydroplanu Morskiego Dywizjonu Lotniczego w Pucku zdjęcia lotnicze osady w Rzucewie (badanej przez prof. Józefa Kostrzewskiego od 1927 r.). W 1935 r. wykonano pierwsze zdjęcia lotnicze Biskupina. W tym samym roku staraniem Władysława Kowalenki sfotografowano grodziska wielkopolskie - była to pierwsza polska dokumentacja lotnicza stanowisk archeologicznych. W latach 1934-1938 archeolodzy Wojciech Kóčka i Zdzisław Rajewski z gondoli zaprojektowanego przez siebie balonu „Pomorze” wykonali dokumentację fotograficzną wykopalisk w Biskupinie. Zdjęcia z balonów wykorzystywano również w okresie międzywojennym do inwentaryzacji grodzisk wczesnośredniowiecznych na terenie Wielkopolski².

W 1955 r. piloci z 62 Pułku Szkolno-Treningowego Lotnictwa Myśliwskiego w Poznaniu wykonali szereg zdjęć kurhanu i cmentarzyska w Łękach Małych. Była to pierwsza polska próba wykorzystania fotografii lotniczej do rekonesansu lotniczego w celu wykrycia nowych stanowisk ${ }^{3}$. Archeologia lotnicza umożliwia odkrycie stanowisk archeologicznych ukrytych na rozległych obszarach pod powierzchnią ziemi, których morfologia nie uległa trwałym przekształceniom4.

Rekonesans lotniczy wykorzystywano także do przygotowania badań geologicznych i prac melioracyjnych. Znaczącym osiągnięciem fotografii lotniczej II RP było wykonanie fotogrametrycznych zdjęć sytuacyjnych rzek Polesia w trakcie przygotowań do melioracji ${ }^{5}$.

Zdjęcia lotnicze są doskonałym źródłem do badania zdarzeń, obiektów i zjawisk związanych z historią wojskową oraz archeologią wojskową. Już w latach 1918-1930 fotogra-

2 Z. Kobyliński, Archeologia lotnicza w Polsce. Osiem dekad wzlotów i upadków, Warszawa 2005, s. 29-39.

3 Ibid., s. 43.

4 Ibid., s. 14.

5 Por. R. Grylaszewski, Zdjęcia sytuacyjne rzek Polesia metodą aerofotogrametryczną, „Prace Biura Melioracji Polesia" t. 1, 1931, z. 5. 
fie lotnicze wykorzystywano we Francji i Belgii do inwentaryzacji grobów wojennych ${ }^{6}$. Od lat osiemdziesiątych XX w. archiwalne fotografie lotnicze często były wykorzystywane jako kluczowy materiał do ustalenia miejsc pochówku ofiar zbrodni hitlerowskich i komunistycznych.

Szczególne znaczenie miało wykorzystanie niemieckich zdjęć lotniczych z archiwów amerykańskich, które oprócz relacji świadków stały się podstawowym materiałem do lokalizacji miejsc pochówków polskich oficerów ofiar Zbrodni Katyńskiej. O wykorzystaniu tych materiałów podczas wyprawy pomiarowej geodetów wojskowych tak pisał Eugeniusz Sobczyński

Podczas drugiej wyprawy w 1991 r. dokonano interpretacji niemieckich zdjęć lotniczych z lat 1942-1944 obejmujących miejsca obozów i mordu polskich jeńców na terenie Rosji i Ukrainy. Na jej podstawie zidentyfikowano miejsca mogił zbiorowych ${ }^{7}$.

Powojenne zdjęcia lotnicze służyły także do lokalizacji grobów więźniów politycznych na Cmentarzu Osobowickim we Wrocławiu oraz Powązkowskim w Warszawie. Fotografie lotnicze służyły do lokalizacji zbiorowych mogił zamordowanych żydów na terenie obozu zagłady Vernichtungslager Kulmhof w Chełmnie nad Nerem. Pracownicy Instytutu Pamięci Narodowej oraz Instytutu Geodezji i Kartografii wykorzystywali również zdjęcia lotnicze do typowania prawdopodobnych miejsc pochówków ofiar Obławy Augustowskiej.

Archiwalne zdjęcia lotnicze współcześnie wykorzystywane są przez służby konserwatorskie do analizy przekształceń poszczególnych obiektów oraz układu architektonicznego i urbanistycznego w trakcie procedury wpisu do rejestru zabytków, a także ujmowania obiektów w gminnej ewidencji zabytków. Historyczne fotoplany Warszawy wykorzystywane są m.in. podczas sporządzania dokumentacji konserwatorskiej oraz inwentaryzacji obiektów zabytkowych na terenie stolicy. Porównanie fotografii lotniczych z różnych okresów umożliwia datowanie powstania i przekształceń oraz zniszczeń wielu obiektów, co w wielu wypadkach utrudnia brak historycznej dokumentacji.

Fotografie lotnicze jako źródło wykorzystywał zespół w składzie: Zbigniew Tucholski, Jacek Wardęcki i Jakub Andrzejewski podczas opracowania inwentaryzacji konserwatorskiej obiektów komunikacji oraz architektury przemysłowej na terenie stolicy, sporządzanej na zlecenie Biura Stołecznego Konserwatora Zabytków.

Archiwalna fotografia lotnicza jest jednym z najistotniejszych źródeł ukazujących urbanistyczny rozwój historyczny miast i obszarów podmiejskich. Zdjęcia lotnicze obrazują nie tylko procesy miastotwórcze, lecz także mechanikę zniszczenia miast oraz chronologiczny przebieg dezurbanizacji i dezindustrializacji. Ukazują także przemiany sieci komunikacyjnej, zmiany w strukturze zalesienia, sieci energetycznych, a także infrastruktury hydrotechnicznej. Fotografie lotnicze są jednym z najważniejszych źródeł

6 D. Dukaczewski, Z. Bochenek, A.K. Karwel, H. Paradysz, Z. Kulikowski, Wykorzystanie danych teledetekcyjnych do poszukiwania miejsc wskazujących na obecność jam grobowych ofiar Obławy Augustowskiej, „Rocznik Geomatyki" t. 15, 2017, z. 1, s. 64.

7 E. Sobczyński, Służba topograficzna w latach 1945-1990, [w:] 90 lat geografii wojskowej, Warszawa 2009, s. 178.

8 D. Dukaczewski, Z. Bochenek, A.K. Karwel, H. Paradysz, Z. Kulikowski, op. cit., s. 63-78. 
do historii techniki, dziejów gospodarczych, a także rozwoju górnictwa głębinowego i odkrywkowego.

Archiwalne zdjęcia lotnicze są także wartościowym źródłem w badaniach historii sportu prowadzonych przez dr. Roberta Gawkowskiego. Umożliwiają lokalizację obiektów infrastruktury sportowej, a także określenie ich formy i wielkości. Wobec znikomego stopnia zachowania źródeł archiwalnych, jak również tymczasowego charakteru obiektów sportowych w okresie międzywojennym i okupacyjnym, często jest to jedyny materiał ikonograficznych obrazujący układ i lokalizację stadionów, strzelnic czy boisk piłkarskich ${ }^{9}$. R. Gawkowski wykorzystywał również fotografie lotnicze w trakcie badań losów Uniwersytetu Warszawskiego w okresie Powstania Warszawskiego ${ }^{10}$.

Dzięki szczegółowej rejestracji czasu wykonania zdjęcia lotnicze z różnych nalotów stanowią wyjątkowe źródło umożliwiające ustalenie ścisłej chronologii wydarzeń historycznych, np. zniszczeń zabytkowych budowli w Warszawie po upadku Powstania Warszawskiego. Fotografia lotnicza ma również szczególną wartość, zastępując zniszczone lub zaginione mapy, plany i dokumentacje techniczne, dotyczące systemów sieciowych bądź poszczególnych obiektów i ich zespołów.

Głównym celem artykułu jest ukazanie znaczenia fotografii lotniczej jako źródła historycznego oraz próba określenia uwarunkowań metodologicznych związanych z wykorzystaniem zdjęć lotniczych w badaniach historycznych. Znaczenie źródłowe i dokumentacyjne fotografii lotniczej przedstawiono, przywołując przykłady ich wykorzystania w badaniach z zakresu historii wojskowej, techniki, komunikacji, architektury i urbanistyki - przedstawiając uzyskane w ten sposób informacje o kapitalnym znaczeniu.

\section{Główne osiągnięcia fotografii lotniczej}

W 1858 r. francuski fotograf, dziennikarz i karykaturzysta Gaspard-Félix Tournachon, znany pod pseudonimem „Nadar", po raz pierwszy sfotografował z balonu na uwięzi fragment Paryża. Dało to początek fotografii wykonywanej z balonów. W 1859 r. w czasie wojny z Austrią „Nadar” odmówił służenia swymi umiejętnościami wywiadowi wojskowemu11. Podczas wojny secesyjnej (1860-1865) w Stanach Zjednoczonych zdjęcia z balonów znalazły praktyczne zastosowanie wojskowe do śledzenia ruchów walczących wojsk. W 1865 r. Konrad Brandel wykonał z gondoli balonu pierwsze zdjęcie Warszawy.

Wykonywanie zdjęć z powietrza stało się znacznie prostsze dzięki wyeliminowaniu przenośnej ciemni fotograficznej. Było to następstwem zastąpienia w 1871 r. przez Anglika R.L. Maddoxa mokrych płyt światłoczułych płytami suchymi. Nowa technika rozprzestrzeniła się szybko w Europie i Stanach Zjednoczonych. Sucha fotografia oraz wprowadzony przez George'a Eastmana film zwojowy umożliwiły miniaturyzację kamer fotograficznych - dzięki temu stało się możliwe ich przenoszenie przez latawce, a nawet gołębie pocztowe. W 1900 r. R.J. Thiele wykonał osiem zdjęć panoramicznych i jedno pionowe dużego fragmentu Moskwy za pomocą zespołu sprzężonych kamer przymocowanych do latawca.

9 Relacja dr Roberta Gawkowskiego z 15.08.2017 r.

10 Por. R. Gawkowski, Krybar. Uniwersytet w cieniu powstańczych walk, Warszawa 2015.

11 L. Deuel, Lot w przeszłość, Warszawa 1984, s. 21. 
Upowszechnienie fotografii lotniczej było wynikiem połączenia dwóch epokowych wynalazków XIX i XX w. - fotografii i lotnictwa. Pierwsze zdjęcia lotnicze z pokładu samolotu wykonał 24 kwietnia 1909 r. w pobliżu Rzymu Wilbur Wright - jeden ze słynnych braci, którzy sześć lat wcześniej dokonali pierwszego udanego lotu samolotem. Z czasem Włosi stali się pionierami zastosowania fotografii lotniczej do celów kartograficznych.

Na podstawie zdjęć lotniczych Włosi wykonali pierwszą mapę Bengazi w Libii. Podczas wojny z Turcją w latach 1911-1912 jako pierwsi wykorzystali również samoloty do celów rozpoznania powietrznego. Fotografia lotnicza początkowo nie była jednak doceniana przez sztaby krajów europejskich. Jedynie w armii pruskiej u progu I wojny światowej zorganizowano sekcje aerograficzne przy oddziałach balonowych.

W 1911 r. rosyjski inżynier wojskowy płk W.F. Potte skonstruował lotniczą kamerę fotograficzną, która stała się pierwowzorem aparatów wykorzystywanych podczas I wojny światowej. Podczas Wielkiej Wojny nastąpił intensywny rozwój fotografii lotniczej, która była powszechnie wykorzystywana przez wszystkie walczące armie do rekonesansu lotniczego i rozpoznania terytorium przeciwnika. W czasie I wojny światowej wprowadzono do kamer lotniczych zmienną przysłonę i migawkę, ulepszono także konstrukcję obiektywów. Umożliwiło to pozyskiwanie zdjęć w różnych warunkach oświetlenia ze znacznie większych wysokości. Pod koniec wojny $25 \%$ wszystkich samolotów biorących udział w walkach było wyposażonych w lotnicze kamery fotograficzne. Podczas walk wojskowa fotografia lotnicza była często nieformalnie wykorzystywana w celu badań stanowisk przez archeologów angielskich, francuskich i niemieckich. Zdjęcia archeologiczne wykonywano również podczas lotów rozpoznawczych, a nawet kierowania ogniem artyleryjskim ${ }^{12}$.

W okresie międzywojennym nastąpił dalszy rozwój fotografii lotniczej, zarówno w zakresie fotogrametrii, jak i fotointerpretacji. Zajmowało się nią wówczas bardzo wielu zdemobilizowanych specjalistów wojskowych. W 1923 r. w zakładach Zeissa skonstruowano stereoplanigraf - urządzenie do fotogrametrycznego opracowania zdjęć. Fotografie lotnicze powszechnie wykorzystywano do celów geodezyjnych i topograficznych, a także w geologii, glacjologii, leśnictwie, gleboznawstwie i archeologii.

W okresie międzywojennym w Polsce wojskowe zdjęcia lotnicze wykonywał i opracowywał Wojskowy Instytut Geograficzny. W 1930 r. przy Polskich Liniach Lotniczych "LOT" utworzono Wydział Aerofotogrametryczny „Fotolot”, który sporządzał podkłady dla celów cywilnych. Polska fotogrametria wojskowa i cywilna w okresie międzywojennym znajdowała się na wysokim poziomie międzynarodowym.

II wojna światowa była okresem niezwykle szybkiego rozwoju fotografii lotniczej dla celów wojskowych. Siły powietrzne wszystkich walczących armii sformowały eskadry fotogrametryczne. Unowocześniano konstrukcję kamer fotograficznych, wprowadzano nowe metody fotografii. Rozwinęły się także techniki interpretacji zdjęć terytorium przeciwnika, co umożliwiało określanie celów bombardowania - obiektów strategicznych, fabryk zbrojeniowych i linii komunikacyjnych. Do największych osiągnięć fotografii lotniczej zaliczyć należy rozpoznanie lotnicze tajnego ośrodka badań nad nowymi broniami III Rzeszy w Peenemünde ${ }^{13}$. W okresie powojennym wraz z eskalacją „zimnej wojny” masowo

13 S.N. Pandey, Principles and Applications of Photogeology, New York 1987, s. 5. 
wykorzystywano fotografię lotniczą do rozpoznania terytorium przeciwnika. Zasoby zdjęć lotniczych z okresu II wojny światowej stały się ważnym materiałem porównawczym do analizy terytorium przeciwnika. Specyfika lotów wywiadowczych na dużych wysokościach wymusiła powstanie nowych konstrukcji kamer lotniczych. Dopiero rozwój techniki satelitarnej, wykorzystywanej do celów wywiadowczych od lat sześćdziesiątych i siedemdziesiątych XX w., odebrał pierwszeństwo fotografii lotniczej ${ }^{14}$.

\section{Wykorzystanie zdjęć lotniczych w historii wojskowej}

Archiwalne fotografie lotnicze są istotnym źródłem do badań historii wojskowej. Na podstawie analizy datowanych zdjęć z różnych nalotów można prześledzić sytuację operacyjną, a także zlokalizować nawet zamaskowane linie obrony, okopy, stanowiska artylerii i broni pancernej.

Zdjęcia lotnicze są bezcennym materiałem w zakresie archeologii pól bitewnych. Ta stosunkowo nowa dziedzina opiera się na analizie źródeł kartograficznych i fotografii lotniczych, w celu odtworzenia obszarów walk i pobojowisk, stanowisk ciężkiej broni oraz miejsc zniszczenia pojazdów pancernych. Umożliwia również odtworzenie topografii lotnisk polowych, baz i składów, szpitali, ziemianek, polowych cmentarzy, a także lokalizacji miejsc, w których spadły zestrzelone samoloty. Analiza archiwalnych fotografii lotniczych w historii wojskowej umożliwia topograficzną lokalizację wydarzeń historycznych na podstawie zachowanych źródeł kartograficznych i ikonograficznych.

Zdjęcia lotnicze są także jednym z najistotniejszych źródeł obrazujących rozwój oraz przemiany fortyfikacji polowej i stałej z okresu I i II wojny światowej. Materiały te mają kapitalne znaczenie dla historii fortyfikacji i budownictwa wojskowego na ziemiach polskich. Wobec zniszczenia bądź trudnej dostępności większości materiałów archiwalnych, a przede wszystkim oryginalnych planów (znajdujących się często w niedostępnych archiwach zagranicznych), są często jedynym źródłem ikonograficznym obrazującym powstanie i bojowe wykorzystanie poszczególnych punktów oporu.

W czasie „zimnej wojny” zasoby fotograficzne Luftwaffe, Armii Czerwonej i wojsk alianckich z okresu II wojny światowej przechowywane w archiwach były przez długie lata niedostępne nie tylko dla historyków. Zdjęcia z okresu wojny obrazujące obiekty wojskowe, poligony i zakłady zbrojeniowe w wielu wypadkach wciąż miały wartość operacyjną jako materiał porównawczy do analizy obiektów militarnych, przemysłu i sieci komunikacyjnej. W największym stopniu materiały te były utajnione w państwach komunistycznych, gdzie również jawne mapy topograficzne poddano ścisłej cenzurze, a równocześnie w sposób zinstytucjonalizowany zafałszowywano ${ }^{15}$. Wzrost zainteresowania historyków europejskich i amerykańskich źródłami fotograficznymi w postaci zdjęć lotniczych widoczny jest od lat osiemdziesiątych XX w., gdy rozwinęły się badania w zakresie historii wojskowej, techniki, komunikacji oraz najnowszych dziejów gospodarczych. Możliwość swobodnego dostępu badaczy z Europy wschodniej do cennego zasobu fotografii lotniczych z archi-

14 A. Ciołkosz, J. Miszalski, J.R. Olędzki, Interpretacja zdjęć lotniczych, Warszawa 1978, s. 11-18.

15 Por. B. Konopska, Wpływ aparatu władzy w latach 1944-1989 na polskie publikacje kartograficzne do użytku publicznego, Warszawa 2012 (Monografie Instytutu Geodezji i Kartografii, nr 16). 
wów wojskowych pojawiła się dopiero na początku lat dziewięćdziesiątych XX w., gdy otwarto archiwa, odtajniono materiały i udostępniono je cywilnym badaczom.

\subsection{Badanie zniszczeń wojennych na przykładzie Warszawy}

Pionierem w zakresie wykorzystania fotografii lotniczych jako źródła historycznego w Polsce był Felicjan Piątkowski, który wraz z L. Kowalskim opracował mapę: Warszawa. Mapa w skali 1:20 000 wraz z inwentaryzacją zniszczeń popełnionych przez Niemców $w$ latach 1939-1945. Mapa opracowana została na podstawie zdjęć lotniczych wykonanych w 1945 r. przez lotników sowieckich dla Biura Odbudowy Stolicy. Mapę wydało Biuro Kartograficzne Głównego Urzędu Pomiarów Kraju w 1949 r. Rozpowszechnianie publikacji zostało wstrzymane przez cenzurę. Kilkanaście egzemplarzy tej mapy przechował sam wydawca w zasobie tzw. egzemplarzy żelaznych ${ }^{16}$. W 1984 r. po zmianach dotyczących procedur cenzurowania publikacji kartograficznych wydany został reprint tej publikacji17. W komentarzu do publikacji F. Piątkowski napisał, że nakład mapy oryginalnej „z trudnych dziś do ustalenia powodów nie został nigdy rozpowszechniony". Wypowiedź tę skomentował Jacek Pasławski, pisząc:

dziwny wydaje się ów brak pamięci Profesora [F. Piątkowskiego - przyp. Z.T.], skoro nie ma już powodów przemilczania tego okresu, gdy źle rozumiana ideologia zapanowała nad zdrowym rozsądkiem [...] nie jest to uwaga na marginesie, lecz moim zdaniem istotna dla pełnej oceny publikacji ${ }^{18}$.

Z kolei pionierem wśród historyków był dokumentalista i varsavianista Zygmunt Walkowski, który w połowie lat osiemdziesiątych XX w. podczas pracy nad opracowaniem i udostępnieniem kronik powstańczych w Wytwórni Filmów Dokumentalnych w Warszawie wykorzystał do analizy topografii powstańczej Warszawy fotografie lotnicze. Stanowiły one cenny materiał uzupełniający i weryfikacyjny, dawały orientację w przestrzeni, umożliwiając lokalizację topograficzną poszczególnych sekwencji powstańczych kronik.

Zdjęcia lotnicze stały się cennym źródłem umożliwiającym opis materiału filmowego. Z. Walkowski stał się ekspertem w zakresie wykorzystania zdjęć lotniczych do badania historii stolicy podczas okupacji.

W 2003 r. Z. Walkowski dotarł do niezbadanego wcześniej przez historyków zbioru fotografii lotniczych Luftwaffe zgromadzonych w Archiwum Narodowym Stanów Zjednoczonych w College Park pod Waszyngtonem. Badając ogromny nieskatalogowany i nieopracowany materiał odnalazł bezcenne zdjęcia z terenu Europy Wschodniej i Polski. Skopiowane przez niego fotografie Warszawy umożliwiają badania: zniszczeń stolicy podczas obrony w 1939 r., zasięgu bombardowań sowieckich z lat 1941-1943, walk powstańczych i lokalizacji poszczególnych barykad, a także chronologii planowego niszczenia miasta po upadku Powstania. Do jego znaczących osiągnięć związanych z wykorzystaniem fotografii lotniczych należy określenie dokładnego czasu wysadzenia w powietrze Zamku

16 Ibid., s. 76-77.

17 J. Kasprzycki, Warszawa jak była. Oryginalne mapy stolicy sprzed 1939 i z 1945 roku, Warszawa 1984.

18 J. Pasławski, Warszawa jak była. Oryginalne mapy stolicy sprzed 1939 i z 1945 roku, „Polski Przegląd Kartograficzny" t. 17,1985, z. 2, s. 87. 
Królewskiego w Warszawie, a także wydanie ekspertyzy sądowej dotyczącej domniemanych komór gazowych KL Warschau. W ekspertyzie tej, także na podstawie analizy źródeł w postaci zdjęć lotniczych, zaprzeczył istnieniu komór gazowych w tunelu pod stacją Warszawa - Zachodnia ${ }^{19}$. Materiały pozyskane przez Z. Walkowskiego mają również istotne znaczenie podczas badań historii infrastruktury miejskiej Warszawy oraz sieci komunikacyjnej stolicy.

Archiwalne wojskowe fotoplany wykorzystuje w swoich badaniach również dr Paweł Weszpiński, varsavianista i historyk kartografii. Materiały te stały się podstawą do opracowania szczegółowej mapy Getta Warszawskiego. W trakcie prac wykorzystał on następujące źródła: plan Warszawy w skali 1:2500, będący aktualizacją planu Lindleya z lat 1936-1941, fotoplan Warszawy z listopada 1935 r., fotoplan Warszawy z 24 września 1939 r., fotografie lotnicze z lat 1939-1945 sprowadzone przez Z. Walkowskiego z archiwum w College Park. Uzupełniającą weryfikację terenu Getta przeprowadził na podstawie sowieckiego fotoplanu z czerwca 1945 r. lub późniejszego niedatowanego z 1946 r. $^{20}$

Na podstawie tych materiałów P. Weszpiński opracował szczegółowych plan Getta Warszawskiego, aktualizowany na koniec września 1939 r. Materiał ten opublikowano jako załącznik (w formie 10 tablic) do drugiego poprawionego i rozszerzonego wydania pracy B. Engelking, J. Leociaka Getto Warszawskie. Przewodnik po nieistniejącym mieście (Warszawa 2013). P. Weszpiński opracował również mapy KL Warschau do niemieckiego wydania książki Bogusława Kopki Das KZ Warschau. Geschichte und Nachwirkungen (Warszawa 2010). Mapy terenu obozu przy ul. Gęsiej autorstwa P. Weszpińskiego były wynikiem analizy zdjęć lotniczych z różnych okresów ${ }^{21}$.

\subsection{Badanie zbrodni wojennych na przykładzie zdarzeń w Miednoje i Charkowie}

W latach 1941-1944 Luftwaffe wykonało wiele zdjęć lotniczych okolic Smoleńska, ponieważ był to ważny węzeł kolejowy i drogowy. Fragment Lasu Katyńskiego w którym zamordowano i ukryto ciała polskich oficerów znalazł się przypadkiem na niewielu z nich. Po zakończeniu wojny zdjęcia lotnicze Luftwaffe w większości zostały przejęte przez armię amerykańską. Znalazły się w National Archives Records Administration w College Park koło Waszyngtonu ${ }^{22}$. Pierwsze analizy i interpretacje zdjęć lotniczych Lasu Katyńskiego wykonywane były w latach pięćdziesiątych i sześćdziesiątych XX w. przez wywiad amerykański, na ten temat brak jest jednak ścisłych informacji. W 1959 r. Wojskowa Służba Kartograficzna (Army Map Services) opracowała dla amerykańskiej Wojskowej Służby Wywiadowczej (US Defence Intelligence Service) na podstawie zdjęć lotniczych pierwszą mapę Lasu Katyńskiego (AMS seria N701, arkusz 4827) ${ }^{23}$.

W 1980 r. fotogrametra i analityk wywiadu amerykańskiego Robert G. Poirier przy współpracy specjalistów z kilku dziedzin nauk po raz pierwszy przeprowadził naukową in-

19 Relacja Zygmunta Walkowskiego 13.09.2017 r.

20 Relacja dr. Pawła Weszpińskiego z 12.09.2017 r.

21 Ibid.

22 Duża kolekcja fotografii lotniczych Luftwaffe znajduje się również w zbiorach fotografii lotniczych Uniwersytetu w Keele w Wielkiej Brytanii.

23 W. Godziemba-Maliszewski, Interpretacja zdjęć lotniczych Katynia w świetle dokumentów i zeznań świadków, „Fotointerpretacja w Geografii" 1995, nr 25, s. 1. Na początku lat 90. XX w. mapa ta została odtajniona na wniosek Wacława Godziemby-Maliszewskego. 
terpretację zdjęć miejsca mordu polskich oficerów w Katyniu. Wyniki swych badań przedstawił w raporcie The Katyn Enigma: New evidence in a 40-year Riddle. Zamieścił w nim i opisał cztery niemieckie zdjęcia lotnicze tego terenu, wykonane w latach 1942, 1943 i 1944. Pierwsze informacje o tym raporcie dotarły do Polski w 1988 r., gdy Zbigniew Rurarz opublikował w Paryżu czasopiśmie „Kontakt” (nr 7-8) artykuł pt. Nieznane zdjęcia cmentarza katyńskiego (Unknown photographs of the Katyń cemetery).

W 1990 r. raport Poiriera został odkryty przez Wacława Godziembę-Maliszewskiego przewodniczącego The Society for Aero-Historical Research w Bethel (USA). GodziembaMaliszewski od połowy lat osiemdziesiątych XX w. badał odtajnione w 1979 r. fotografie lotnicze Luftwaffe ze zbiorów National Archives oraz Biblioteki Kongresu24. Wiosną 1990 r. odbitka kserograficzna tego raportu wraz z licznymi kopiami zdjęć lotniczych Lasu Katyńskiego oraz dokumentów, zostały przekazane przez Godziembę-Maliszewskiego polskiej prokuraturze i kilku badaczom problematyki katyńskiej.

W 1991 r. w Pracowni Fotointerpretacji Geograficznej Wydziału Geografii i Studiów Regionalnych Uniwersytetu Warszawskiego wykonano fotointerpretację zdjęć otrzymanych od Godziemby-Maliszewskiego. Wynikiem tych prac prowadzonych przez dr Małgorzatę Mycke-Dominko oraz Jana R. Olędzkiego były cztery pierwsze polskie mapy obrazujące obszar Lasu Katyńskiego. Wyniki tych badań opublikowała Małgorzata Mycke-Dominko w artykule pt. Zmiany na obszarze lasu katyńskiego w latach 1942-1944, na podstawie analizy zdjęć lotniczych („Fotointerpretacja w Geometrii” 1992, nr 22, s. 111-121). Na podstawie tych zdjęć we współpracy z Janem R. Olędzkim opracowała mapy Lasu Katyńskiego 25 .

W tym samym roku analizę zdjęć Luftwaffe wykonano w Zarządzie Topografii Sztabu Generalnego Wojska Polskiego. Celem tych prac była lokalizacja terenowa miejsc pochówku oficerów związana z przygotowaniami do badań sondażowych poprzedzających prace ekshumacyjne. Za pomocą analiz fotogrametrycznych wytypowano potencjalne lokalizacje miejsc pochówku polskich oficerów w Miednoje i Charkowie. Materiałem badawczym były pochodzące z archiwów amerykańskich niemieckie fotografie, wykonane w czasie czterech nalotów w różnym czasie. Materiałem pomocniczym w trakcie analizy zdjęć były również amerykańskie kalki analiz z 1953 r. oraz opisy parametrów lotów.

Analizę powierzono dwóm fotogrametrom wojskowym, którzy wykonali ją metodą stereoskopową. Analiza materiału prowadzona była przez nich w ciągu tygodnia na dwie zmiany.

W pierwszej kolejności zdjęcia zorientowano w przestrzeni geograficznej, wykorzystując w tym celu źródła kartograficzne. Podczas interpretacji posiłkowano się opisami terenowymi oraz zeznaniami świadków i jeszcze żyjących na początku lat dziewięćdziesiątych XX w. uczestników zbrodni.

Punktem orientacyjnym, od którego rozpoczęto analizę, była droga oraz dacza NKWD, o której było wiadomo na podstawie zeznań pracownika NKWD uczestniczącego w egzeniczych Treblinki i Babiego Jaru, por. W. Godziemba-Maliszewski, Babi Yar and Rep'yahiv Yar. Reconciliation of 1942 GX Luftwaffe Aerial Photos with 1941 Wehrmacht Imagery Taken by Jahannes Hähle, [w:] The Materiality of Troubled Pasts Archaeologies of Conflicts and Wars, Warszawa, Szczecin 2017, s. 41-55.

25 M. Mycke-Dominko, Zmiany na obszarze lasu katyńskiego w latach 1942-1944, na podstawie analizy zdjęć lotniczych, „Fotointerpretacja w Geometrii" 1992, nr 22, s. 111-112. 
kucjach, Mitrofana Syromiatnikowa ${ }^{26}$. Bardzo szybko udało się wyznaczyć miejsce, gdzie na fotografiach z ostatniego nalotu widoczne było zapadlisko ziemne w formie sinusoidy. Obszar ten wytypowano jako pierwszy do sprawdzenia w terenie. Badania sondażowe wykonane bezpośrednio w miejscu, które wskazano na zdjęciu, potwierdziły hipotezę wystąpienia pochówku. Dalsze badania materiału pobranego w terenie potwierdziły prawidłowe wskazanie lokalizacji dołów śmierci polskich oficerów w Miednoje ${ }^{27}$. Znacznie trudniejsze było odnalezienie miejsc pochówku zamordowanych oficerów w Charkowie. Wykorzystując zeznania świadków i opisy zlokalizowano tzw. czarną drogę prowadzącą na teren „zony" NKWD. W toku dalszej analizy zdjęć wyznaczono miejsce pochówku na północny-wschód od Charkowa. Także ta lokalizacja została potwierdzona podczas późniejszych odwiertów sondażowych dołów śmierci i ekshumacji. Szczegółowa lokalizacja miejsc pochówków polskich oficerów w Miednoje i Charkowie w wyniku analizy archiwalnych fotografii lotniczych (potwierdzona w trakcie badań sondażowych i ekshumacyjnych) było dużym sukcesem wojskowych fotogrametrów ${ }^{28}$.

\subsection{Badanie sieci wojskowych linii kolejowych}

Fotografie lotnicze wykorzystywane są również w badaniach nad rozwojem sieci komunikacyjnej w okresie I wojny światowej. W publikacjach Andrzeja Tajcherta niemieckie fotografie lotnicze wobec braku zachowanych planów i dokumentacji budowanej oraz eksploatacyjnej są często jedynym źródłem obrazującym przebieg terenowy wojskowych wąskotorowych kolei polowych z okresu I wojny światowej (istniejących często tylko przez kilka tygodni, demontowanych po przesunięciu się frontu). W pracach A. Tajcherta zdjęcia lotnicze zamieszczane są także jako wartościowy materiał ilustracyjny ${ }^{29}$.

Źródła w postaci archiwalnych fotografii lotniczych wykorzystuje również autor niniejszego artykułu w badaniach historycznego rozwoju sieci kolejowej obiektów industrialnych, a także wspólnie z Anną Mistewicz podczas analizy powstania śródlądowych portów Warszawy ${ }^{30}$. Archiwalne zdjęcia lotnicze były również bardzo pomocne w trakcie opracowania kilku inwentaryzacji konserwatorskich obiektów infrastruktury komunikacyjnej i przemysłowej.

\section{Podsumowanie}

Fotografia lotnicza (zdjęcie) stanowi obraz zapisany dowolną techniką fotograficzną. Jako źródło historyczne jest stosunkowo rzadko wykorzystywana przez historyków, dlate-

26 K. Persak, Ekshumacje katyńskie. Prace archeologiczno-ekshumacyjne w Charkowie, Katyniu i Miednoje w latach 1991-1996 i ich wyniki, „Biuletyn IPN” 2010, nr 4, s. 41.

27 Relacja z 13.07.2017 r. anonimowego pracownika Zarządu Topografii Sztabu Generalnego WP uczestniczącego w tych pracach.

28 Ibid. Dopiero po zakończeniu analizy archiwalnych zdjęć lotniczych z okresu wojny otrzymano od strony rosyjskiej współczesne zdjęcia lotnicze tych terenów wykonane z helikoptera.

29 Por. A. Tajchert, Kolej wąskotorowa Zwierzyniec - Biłgoraj, Łódź 2007; idem, Kolej wąskotorowa Wieluń Praszka - Olesno, Rybnik 2013; idem (wraz z. A. Wawrzyniakiem i M. Zajfertem), Kolej wąskotorowa Rogów - Rawa - Biała, Rybnik 2014; idem, Koleje wąskotorowe na Kurpiach, Rybnik 2015.

30 A. Mistewicz, Z. Tucholski, Wiślane porty Warszawy, Historia infrastruktury żeglugi śródlądowej stolicy, Warszawa 2017. 
go też występuje wiele niejasności metodologicznych, bibliograficznych i warsztatowych w tym zakresie.

Przechodząc do postulatów metodologicznych, należy rozróżnić odczytywanie obrazów (zdjęć), czyli wykrywanie obiektów i zjawisk na podstawie oznak widocznych bezpośrednio na obrazie, od interpretacji, czyli użycia w procesie odczytywania wskaźników szerszych niż tylko zarejestrowane na obrazie. Dla historyka tym narzędziem jest przede wszystkim wiedza zawarta w innych źródłach archiwalnych, opisowych oraz relacjach.

Większość badaczy w pewnym zakresie opracowało własną metodologię badań archiwalnych fotografii lotniczych. Ze względu na brak w polskim piśmiennictwie z zakresu metodologii badań historycznych prac dotyczących fotografii lotniczej, postulatem tego artykułu jest opracowanie zasad opisu bibliograficznego fotografii lotniczych i ich cytowań.

Zdjęcia lotnicze ze względu na formę fizyczną należałoby zakwalifikować do źródeł ikonograficznych, jednak charakter odwzorowania rzeźby terenu i topografii danego obszaru kwalifikuje je także do źródeł kartograficznych. Kwestia ta pozostaje nadal otwarta i należy ją poddać krytyce specjalistów w zakresie metodologii badań historycznych i dziejów kartografii.

Zdjęcia lotnicze stanowiące datowaną rejestrację historycznej topografii terenu mają przewagę jako źródło nad mapami, które są odwzorowaniem w formie przetworzonej przez kartografów, często według nieścisłej chronologicznie aktualizacji.

Ze względu na problemy natury metodologicznej i organizacyjnej oraz trudności finansowe archiwalne fotografie lotnicze nie są powszechnie udostępniane w kraju w formie cyfrowej online. Znaczenie wzorcowe dla takiej formy prezentacji zasobu archiwalnych fotografii lotniczych ma projekt Biura Geodezji i Katastru m.st. Warszawy, obejmujący ich przetworzenie do postaci ortofotomapy. Na stronie internetowej udostępniono w formie współrzędnych warstw następujące fotoplany Warszawy: 1935 r. i 1945 r., plany z lat siedemdziesiątych, osiemdziesiątych, dziewięćdziesiątych XX w. oraz współczesne ${ }^{31}$. Taka forma prezentacji zbiorów ma istotne znaczenie dla upowszechniania historii stolicy, ukazuje w porządku chronologicznym zniszczenie Warszawy po upadku Powstania Warszawskiego, a także jej odbudowę i powojenny rozwój urbanistyczny. Cyfrowa ortofotomapa umożliwia porównanie ze współczesnymi zdjęciami historycznych obrazów wybranego obszaru miasta.

Fotografie lotnicze z okresu międzywojnia, II wojny światowej i PRL stanowią cenne źródło historyczne. Postulatem autora jest digitalizacja i udostępnienie w formie cyfrowej zasobów archiwum fotogrametrycznego dawnego Zarządu Topografii Sztabu Generalnego WP. Materiały te obecnie znajdują się w zbiorach Centralnego Archiwum Wojskowego w Rembertowie. Obejmują one wielką liczbę zdjęć od 1944 r., aż po kres PRL-u. Zdjęcia są uporządkowane i posiadają skorowidze, jednak archiwiści w zasadzie nie udostępniają tego cennego materiału.

Z zagadnieniem udostępnienia tego zasobu wiąże się kwestia odtajnienia zdjęć z okresu „zimnej wojny” nadal posiadających klauzulę tajności, co bardzo utrudnia badania powojennych fotografii. Szybki rozwój technik rozpoznania satelitarnego oraz dezaktualizacja operacyjna tego archiwalnego materiału sprawiają, że utrzymywanie klauzuli tajności 
materiałów z lat pięćdziesiątych, sześćdziesiątych i siedemdziesiątych XX w. jest anachronizmem poprzedniej epoki „totalnego” nadzoru nad kartografią i fotogrametrią.

Opracowanie i udostępnienie zbiorów fotografii lotniczej w formie cyfrowej jest bardzo czasochłonne i kosztowne, dlatego też digitalizacja cennego zasobu fotografii lotniczych dawnego Zarządu Topografii Sztabu Generalnego WP powinna stać się tematem projektu archiwalnego finansowanego z zewnętrznych środków. Prezentowane online w formie ortofotomapy cyfrowej historyczne fotografie lotnicze obejmujące cały obszar Polski (z różnych okresów) byłyby kapitalnym materiałem dla historyków i kartografów. Ze względu na specyfikę zbioru do jego opracowania i digitalizacji powinni zostać zatrudnieni nie tylko archiwiści, lecz również fotogrametrzy oraz kartografowie.

Nie mniej istotna jest kwestia instytucjonalnego i finansowego wsparcia dla badań prowadzonych w archiwach zagranicznych. W tym przypadku konieczne jest pozyskanie kopii archiwalnych zdjęć z terenu ziem polskich, sprowadzenie ich do kraju i udostępnienie w jednym z archiwów oraz w formie cyfrowej.

W przypadku badań z zakresu historii wojskowej, techniki i komunikacji konieczne jest nawiązanie ścisłej współpracy archiwistów, historyków, fotogrametrów oraz kartografów w celu prowadzania specjalistycznych analiz archiwalnych fotografii z wykorzystaniem profesjonalnego instrumentarium i nowoczesnych technologii.

\section{Bibliografia}

Barber M., A History of Aerial Photography and Archaeology. Mata Hari's Glass Eye and Other Stories, Swindon 2011.

Ciołkosz A., Miszalski J., Olędzki J.R., Interpretacja zdjęć lotniczych. Warszawa 1978.

Deuel L., Lot w przeszłość, Warszawa 1984.

Dukaczewski D., Bochenek Z., Karwel A.K., Paradysz H., Kulikowski Z., Wykorzystanie danych teledetekcyjnych do poszukiwania miejsc wskazujących na obecność jam grobowych ofiar Obławy Augustowskiej, „Rocznik Geomatyki” t. 15, 2017, z. 1.

Engelking B., Leociak J., Getto Warszawskie. Przewodnik po nieistniejącym mieście. Warszawa 2013.

Gawkowski R., Krybar. Uniwersytet w cieniu powstańczych walk, Warszawa 2015.

Godziemba-Maliszewski W., Babi Yar and Rep'yahiv Yar. Reconciliation of 1942 GX Luftwaffe aerial photos with 1941 Wehrmacht imagery taken by Jahannes Hähle, [w:] The Materiality of Troubled Pasts Archaeologies of Conflicts and Wars, Warszawa, Szczecin 2017.

Godziemba-Maliszewski W., Interpretacja zdjęć lotniczych Katynia w świetle dokumentów i zeznań świadków, „Fotointerpretacja w Geografii” 1995, nr 25.

Grylaszewski R., Zdjęcia sytuacyjne rzek Polesia metodą aerofotogrametryczną, „Prace Biura Melioracji Polesia" t. 1, 1931, z. 5.

Jabłoński Z., Sinkiewicz M., Klucz fotointerpretacyjny wybranych elementów środowiska kulturowego środkowej części polski północnej, Toruń 1993.

Kasprzycki J., Warszawa jak była. Oryginalne mapy stolicy sprzed 1939 i z 1945 roku, Warszawa 1984. 
Kobyliński Z., Archeologia lotnicza w Polsce. Osiem dekad wzlotów i upadków, Warszawa 2005.

Konopska B., Wpływ aparatu władzy w latach 1944-1989 na polskie publikacje kartograficzne do użytku publicznego, Warszawa 2012 (Monografie Instytutu Geodezji i Kartografii, $\mathrm{nr}$ 16).

Kopka B., Das KZ Warschau. Geschichte und Nachwirkungen. Warszawa 2010.

Mistewicz A., Tucholski Z., Wiślane porty Warszawy, Historia infrastruktury żeglugi śródlądowej stolicy, Warszawa 2017.

Mycke-Dominko M., Zmiany na obszarze lasu katyńskiego w latach 1942-1944, na podstawie analizy zdjęć lotniczych, „Fotointerpretacja w Geometrii” 1992, nr 22.

Pasławski J., Warszawa jak była. Oryginalne mapy stolicy sprzed 1939 i z 1945 rok, „Polski Przegląd Kartograficzny” t. 17, 1985, z. 2, s. 86-87.

Persak K., Ekshumacje katyńskie. Prace archeologiczno-ekshumacyjne w Charkowie, Katyniu i Miednoje w latach 1991-1996 i ich wyniki, „Biuletyn IPN” 2010, nr 4, s. 41.

Pandey S.N., Principles and Applications of Photogeology, New York 1987.

Sobczyński E., Służba topograficzna w latach 1945-1990, [w:] 90 lat geografii wojskowej, Warszawa 2009.

Tajchert A., Kolej wąskotorowa Wieluń - Praszka - Olesno. Rybnik 2013.

Tajchert A., Kolej wąskotorowa Zwierzyniec - Biłgoraj, Łódź 2007.

Tajchert A., Koleje wąskotorowe na Kurpiach, Rybnik 2015.

Tajchert A., Wawrzyniak A., Zajfert M., Kolej wąskotorowa Rogów - Rawa - Biała. Rybnik 2014.

\section{Podziękowania}

Autor serdecznie dziękuje Pani Profesor Beacie Konopskiej (UMCS) za cenne uwagi i wskazówki źródłowe.

dr hab. Zbigniew Tucholski, prof. PAN, jest historykiem techniki i komunikacji, pracownikiem Instytutu Historii Nauki im. L. i A. Birkenmajerów PAN. Nr tel. 226572746.

Data zgłoszenia artykułu: 9 marca 2018

Data przyjęcia do druku: 18 stycznia 2019 